УДК 811.161.2

Т. М. Мішеніна, К. А. Качайло

\title{
СТИЛІСТИЧНИЙ РЕСУРС ОДНОСКЛАДНИХ РЕЧЕНЬ У ВІДТВОРЕННІ СИНЕСТЕЗІЙНОЇ ПРИРОДИ ХУДОЖНЬОГО ТЛА
}

Мішеніна Т. М., Качайло К. А. Стилістичний ресурс односкладних речень у відтворенні синестезійної природи художнього тла.

Публікацію присвячено розкриттю стилістичного ресурсу односкладних речень, структурно-семантичні особливості яких відтворюють синестезійну природу художньої архітектоніки. Досліджено типові синестезійні образи, застосовувані в мовній системі; проаналізовано механізми утворення i функціонування синестезійних образів; розглянуто аспект вироблення естетичної 
чуттєвості в аспекті спрямування естетичного знання в розробленні синестезійних мовних образів в українській літературній традиції загалом, літературі рідного краю зокрема. Акцентовано на тому, що сформований контент синестезійних мовних образів становить стилістичний ресурс мовної системи.

Ключові слова: синестезія, синестезійний художній образ, естетика художнього твору, односкладне речення, стилістичний потенціал односкладних речень.

Мишенина Т. М., Качайло К. А. Стилистический ресурс односоставных предложений в воспроизведении синестезийного содержания художественного фона.

Публикация посвящается раскрытию стилистического ресурса односоставных предложений, структурно-семантические особенности которых воспроизводят синестезийную природу художественной архитектоники. Исследуются типичные синестезийные образы, применяемые в языковой системе; проанализированы механизмы создания и функционирования синестезийних образов; рассмотрен аспект формирования эстетической чувственности в аспекте развития эстетического знания в разработке синестезийных языковых образов в украинской литературной традиции в целом, литературе родного края в частности. Акцентируется внимание на том, что сформированный контент синестезийных языковых образов составляет стилистический ресурс языковой системы.

Ключевые слова: синестезия, синестезийный художественный образ, эстетика художественного произведения, односоставное предложение, стилистический потенциал односоставных предложений.

Mishenina T. M., Kachaylo K. A. Stylistic drawing of simple sentences in representation of the synesthetic nature of the art background.

The publication reveals the stylistic resource of simple sentences, the structuralsemantic features of which reflect the synesthetic nature of art architechtonic (on the example of works created by the native land writer Olesya Omelchenko). Typical synesthetic images used in the language system are characterized on theoretical level; the mechanism of synesthetic images foundation and functioning is analyzed; the aspect of creation of esthetic sensuality with the view of the tendency of esthetic knowledge in the development of synesthetic language images in Ukrainian literary tradition as a whole and in the literature of native land particularly is described.

Paying attention that synesthesia is considered to be a system sign of esthetic sensuality and also causes a new approach to the investigation of the problem of sensuality the article covers practical realization of possibilities of associating different types of perception, the interrelation of feelings in the act of perception of both reality and work of art, the research of the structure of polymodal perception on the level of () Т. М. Мішеніна, К. А. Качайло, 2018. -162- 
images studied, and also style-forming sign of idiostyle when in the only cognitive act the involvement of different types of associations is performed and is in its turn one of the tendencies of a new view on art potential of language units as a part of art images.

Psycholinguistic interpretation in the contents of linguistic analysis of synesthetic images representing the art background of Olesya Omelchenko allows to isolate and characterize a proper sensor component (feelings); a sensor-emotional component (psychological signs of emotion / state; corporal signs of emotion / state (information of corporal feelings, which the person experiences in this or that state; exterior signs of emotion / state ( information about the situations in which the person has a certain internal experience). The formed contents of synesthetic language images make a stylistic resource of language system and also are the defining sign of formation of valuable dominant and esthetic imperative of the language personality reflecting the esthetics of the work of art.

Key words: synesthesia, synesthetic art image, esthetics of the work of art, simple sentence, stylistic potential of simple sentences.

Синестезійне художнє тло репрезентує дійсність у іï складному обширові, що виявляє не лише естетику художнього сприйняття, але й засвідчує стилістичний ресурс художніх образів, які мають маркерами перцепційні характеристики. Явище синестезії на сучасному етапі розвитку наукової думки стало предметом вивчення психології, лінгвістики, літературознавства, естетики, філософської антропології, семіотики, інших гуманітарних наук. Про сутність синестезії дослідники говорять із XIX століття, визначаючи іï як «одночасне відчуття» або «міжчуттєвий зв'язок». За сучасними науковими даними, визначення суті базового поняття синестезії, його обсягу зазнали трансформацій певного характеру.

Н. Дмитренко у статті «Звук і колір: феномен синестезії у творчому мисленні Я. Івашкевича (на матеріалах українськомовних видань)» зауважує: «знакам, що викликають синестезію, властива сугестивна функція. Синестетичний механізм робить свій внесок в існування художнього образу як ознаки будьякого мистецтва. Очевидно, що літературна, вербальна синестезія має низку особливостей, які відрізняють іï від інших видів синестезій, наприклад, зорової чи слухової, у яких задіяні 
безпосередньо органи відчуттів під час реакції на зовнішні подразники» [1].

Викладена позиція засвідчує: вербальна синестезія має основою рефлексію герменевтичного трактування художнього образу, відтворює реакції на безпосередні подразники. Одночасно спостережуване в контексті слово здатне засвідчувати емоційну реакцію на зовнішній вплив, що дає змогу виокремити сенсорноемоційний складник у структурі синестезійного образу. Синестезійний образ, будучи полікомпонентним із позиції сенсорно-емоційного корелята, $€$ найбільш важливим для творення та сприйняття естетичного вербального простору.

У працях, присвячених 3'ясуванню суті синестезії, які розширюють уявлення про природу синестезійного образу з позиції лінгвописхології, Л. Виготський, Л. Маркс, М. МерлоПонті, С. Осгудт зазначають, що синестезія $\epsilon$ не тільки міжчуттевими зв'язками, а виступає результатами реалізації цих зв'язків у певних царинах - поетичні тропи міжчуттєвого змісту, кольорові та просторові образи, узаємозв'язок між мистецтвами. До однієї з форм абстрактного асоціативного творчого мислення, яка охоплює не лише когнітивний, а й емоційно-почуттєвий акт, зараховують синестезію С. Рубінштейн i $\quad$ Б. Галєєв. Похідною реакцією підсвідомості визначають синестезію дослідники психоаналітичного напрямку К. Юнг, І. Єрмаков.

О. Сарнавська у праці «Інваріантність інтерпретації синестезії та її роль в естетичній чуттєвості», подаючи теоретичне обгрунтування й аналіз практичного втілення можливостей об’єднання різних типів сприйняття, підкреслює: «Синестезія, як гармонійне полімодальне сприйняття, при якому в єдиному когнітивному акті відбувається задіяння різних за типом асоціацій, i $є$ одним із напрямків нового погляду на творчі можливості особистості, розвиток нових шляхів розширення творчого потенціалу людини» [4]. Відповідно, екстраполяція синестезії має такі вектори: а) психологічний (нейрофізіологічне вивчення

() Т. М. Мішеніна, К. А. Качайло, 2018. -164- 
діяльності кори головного мозку 3 позиції синестезійного сенсорного пізнання дійсності; спосіб цілісного сприйняття); б) лінгвістичний (розуміння синестезії як мовної універсалії, що фіксує міжчуттєвий зв'язок за допомогою слів; на рівні стилістичного ресурсу - як метафоричні тропи і фігури й символи, створені на міжчуттєвих переносах); в) мистецький (синестезія становить предмет вивчення мистецтвознавства; дослідження механізмів утворення синестезійних образів у різних видах мистецтва розширює уявлення щодо естетичної вартості твору мистецтва).

Лінгвістичний аналіз синестезійного художнього образу уможливлює його розгляд із грунтуванням на сенсорно-емоційній узаємодії в цілісній системі людської чуттєвості.

Важливо зазначити, що синестезія, на думку сучасних науковців, у широкому піi потрактуванні обов'язково присутня у творчості будь-якого поета чи прозаїка.

Мета статті - з'ясувати специфіку використання односкладних речень у поезії Олесі Омельченко як засобу відтворення синестезійної природи художніх образів. Джерелом дослідження стала збірка ії поетичних творів «Вселюбов», яка вміщує поезії, поеми, балади, драми, уривок з роману.

Олеся Омельченко - це сучасна письменниця рідного краю (Дніпропетровщини), з 1997 року є членом Національної Спілки письменників України, а з 2002 року прийнята до Національної Спілки журналістів України.

Цікаво, що саме односкладне означено-особове речення відображає кредо поетеси: I не стомлюсь захоплюватись барвним багатомірним світом досконалим, в якому диво-зіркою лечу (3, с. 9); Живу і квітну у магічнім Слові заради вас, о земле дива й чуда, заради вас, прекрасне моє людство (3, с. 9-10).

Послуговуючись найрізноманітнішими синтаксичними конструкціями, письменниця надає перевагу означено-особовим односкладним реченням. До таких одиниць зазвичай вдаються, 
коли немає потреби акцентувати увагу на адресантові мовлення (1 або 2 особі однини чи множини), відповідно, у поетичному тексті реалізується його стилістична індивідуальність. «Своєрідність їх стилістики полягає передусім в економній, але дуже характерній формі вираження певної думки» [2, с. 239].

Саме стилістичний ресурс односкладних речень допомагає відтворити синестезію художніх образів у поетичній творчості Олесі Омельченко. Зміст і форма синтаксем несуть специфічний емоційний заряд, підсилюючи естетичну реакцію читача.

Аналіз односкладних означено-особових речень, наявних у поезії письменниці, дає змогу говорити про вербальну синестезію: слово містить рефлексивний компонент, що відбиває реакції на безпосередні подразники, й одночасно виступає емоційною реакцією на зовнішній вплив. Сконденсована подача інформації такого характеру синтаксичних одиницях викликає сприйняття більших обсягів значень завдяки звукообразним засобам i стилістичним прийомам. Синестезійні переживання реципієнта таких особливостей мови мають велике значення при цілісному сприйнятті літературного твору.

Дібраний фактичний матеріал засвідчує, що через означеноособові односкладні речення переважно реалізується взаємодія звуку й кольору, наприклад: Лечу в промінні тиха й урочиста (3, с. 50); Зараз умить в інший вимір полинем, квітами станемо, шепотом, світлом (3, с. 51); В тиші прозорій в оголену спеку злиднів продовжите лиш картотеку (3, с. 57); Ступлю назустріч - потону в сіянні, прислухаюсь, як дихає земля... (3, с. 14); Із підземелля снів золотокосих, Із королівства чудернацььких снів біжу крізь літо, ще малеча боса, $і$ чую шепіт $і$ ледь чутний спів 3 листків трави і променів щцасливих, Із пелюсток трояндових в росі, і припадаю поглядом тремтливим до ніжнотонних звабних голосів (3, с. 60); Народжуюсь з грому і блискавки $і$ спадаю до спраглих корінчиків, $і$ здіймаюсь у небеса із дихаючого лона Землі (3, c. 87).

(ㄱ Т. М. Мішеніна, К. А. Качайло, 2018. -166- 
Наведені фрагменти уможливлюють виокремлення таких особливостей художнього живопису Олесі Омельченко: протиставлення на рівні звукових вимірів (тиша - голос / звук / гучність); перевага фонового «рухливого» кольору (спектральний вимір з урахуванням таких іманентних характеристик, як фон, ритм, тон, світлотність), що суттєво розширює асоціативний діапазон сприйняття (небеса, проміння, блискавка).

Стилетворчим чинником ідіолекту Олесі Омельченко $є$ синестезія, побудована на тактильних асоціаціях, що дає змогу авторові передати плинне враження настрою, певну філософську позицію: У мить ясну до серия пригорни (3, с. 74); Любове, не вмирай! Тримай мене міиніше у обіймах. Я п'ю твій мед, сповідую твій рай, невільниця й водночас королівна (3, с. 74). Сенсорна образність грунтована на наявних моделях поведінки особи ліричний герой відчуває дотичність до фізичного тіла, насолоджуючись теплом, ласкою й ніжністю 3 одного боку й переживає певні душевні стани з іншого

Поетичні рядки - Не йдіть, печальні холоди! Моє обличчя освіти, ще не холодне добре сонце! (3, с. 80); На сонце надивіться! По ипоришу м'якому находіться! (3, с. 82); Намріюсь, нароблюсь на грядиі, усядусь в теплім шпориші, заструменять протубераниі $і$ стане тепло на душі $(3$, с. 89) засвідчують суголосність емоцій і природної характеристики зіставлюваних об'єктів (сонце - теплота; яскравість / доброта; щзирість відкритість / світлота); суголосність тактильних й емоційних асоціатів (м'який / теплий шпориш - тепло на душі (відчуття безпосереднє та пов'язане з відчуттям рідної землі).

Неозначено-особові речення в ідіостилі Олесі Омельченко мають звукові характеристики: 1) гучність як ознака досягнення мети / налаштування / заклик до боротьби: У бубни били радо, верещзали, біля багаття в'юнились у таниі, мечі бряжчали, і ножі блищали (3, с. 33); - До бою! За честь! - затрубили (3, с. 38); 2) мовчання як протистояння / втома: Але ж бо як втомилися 
мовчать (3, с. 60); 3) звук, зокрема якість звуку - сичання - як корелят емоції - підступності, відповідно духовної дії зради, зречення: І сичали, мов гади. Бруд кидали в спину (3, с. 138).

За нашим спостереженням, інфінітивні речення мають синестезійний закличний відтінок, спонукання до звитяжних дій, які покликані гармонізувати соціокультурну дійсність, мікросвіт окремої душі: Мамай із шатра заревів: - Повернуть! В погоню! (3, с. 34); Творить ясну історію так просто! (3, с. 92).

Відчуття довкілля як макросвіту, як перебігу початків i завершень, причинно-наслідкових коловоротів репрезентоване в синестезійному образові душі, яка є суб'єктом переживання конструктивних / деструктивних емоцій (іноді - у поєднанні 3 тактильними корелятами); констатуємо спонукання до пізнання сутності макросвіту: У суворій стиглості впасти в сни врочисті, сили набиратися для цзвітіння й плоду (3, с. 66); Відпочити, вистоять зиму июю холодну (3, с. 66-67); і припасти заспраглими 3 роду вустами до нектару живильного всіма чуттями (3, с. 142).

Екзистенція художнього тла Олесі Омельченко $\epsilon$ протистоянням добра / зла; співмірності і рефлексії вартості / марності життя (праці). Почасти добро / зло поеткою зіставлюване 3 рядом життя / смерть, що апелює, безумовно, до християнського пізнання світу: I помру між краси, щуоб ожить в казках! (3, с. 103); Слабкі таке нароблять з переляку, аби прожити день свій недарма (3, с. 103); Так просто, виявляється, піти з життя, иієї сонцесяйної планети, немов переступить поріг оселі і вийти в двір (3, с. 149); Отак межу тонкої паралелі у час призначений умить переступить із криком болю у фізичнім тілі та жахом у свідомості своїй (3, с. 149).

Стилістичний ресурс безособових речень у творчості Олесі Омельченко репрезентує такі синестезійні паралелі:

1. Настанова щодо правомірної / неправомірної поведінки, де моральний імператив являє собою не стільки моральну настанову, скільки настанову пізнавати світ шляхом пізнання 
причинно-наслідкового поступу, розвитку, розвою: Обережно життя! В нього треба ввіходить чистими (3, с. 12); Але й розбитись треба вчасно (3 с. 72); Треба вижити! Поєднатися із корінням иій кроні вітряній, помудрішати й не боятися оживить себе в пісні, в імені, бо так можна $i$ відірватися, безтілеснодуховно згинути (3, с. 88).

2. Застереження, що стосується як неможливості переступу сакрального, так і настанови лінії поведінки (у підтексті - яке не дотримується заповідей), пор.: 3 Богами так не можна! Їм видніше! Їх зрадимо - відвернуться й вони (3, с. 26); Не можна такій у зубастім суспільстві - з'їдять (3, с. 54).

3. Паралелізм на рівні:

a) спектральних характеристик і внутрішніх станів: $B$ мені світає, й зоря на пружному крилі всміхнеться днем у світлу долю (3, с. 18); Смутно вечоріс (3, с. 61); Та все одно стане ж радіснозоряно (3, с. 78); Щодалі важче в сутінках іти (3, с. 61);

б) тактильних характеристик i внутрішніх станів: Oй холодить по всій моїй землі (3, с. 168); Судомить небо, туманіє сонно (3, с. 168); Стало страшно і пусто, й зимно (3, с. 131);

в) звукових характеристик і внутрішніх станів: Шепотомспогадом із підсвідомості з пам'яті роду так щемно щасливиться, наче словенські Боги в душу дивляться (3, с. 79), де звукова характеристика апелює до сакрального пізнання, закладеного темпорально як на генетичному рівні, так і на рівні розвитку релігійно позначеної світоглядної позиції;

г) одоративних характеристик $\mathrm{i}$ внутрішніх станів: У прохолоді гостро пахне димом, І яблуками, й листям, й полином, I стомленій душі смиренно й тісно, мов юна казка завітала в сон $(3$, c. 13$)$, де наявний автохтонний фітонімний корелят, що рефлексує з поняттям ріднизни, відповідно, маємо стягнення казка - душа - земля;

д) густативних характеристик i внутрішніх станів: Як солодко жити в пульсуючій тайні $(3$, с. 94$)$, де констатуємо також 
підтекст звукового фону (тайна асоціюється 3 тишею; актуалізуються семи непоширення таємниці на загал, сакральність iii природи), що посилює експресивність шляхом використання дієприкметника пульсуюча (тайна), тобто таємниця, що становить іманентний складник світобудови, який потребує пізнання.

Номінативні речення мають констатувальний характер у художньому дискурсі, водночас констатація, акцентуючи на певній відчуттєвій характеристиці, апелює до рефлексії в пізнанні дійсності через певний перцепційний корелят.

Мовний матеріал засвідчує такі синестезійні характеристики:

а) спектральні стягнення 3 конструктивними / деструктивними емоціями; констатуємо відповідність сонце / радість / надія; українська лінгвокультура апелює до фітонімних символів, що актуалізує відповідні колірні маркери: Жоржинне сонце, добре небо, й вогнем у день новий займусь $(3$, с. 18$) ; A$ сонцее! $O x$, високе сонце! (3, с. 64); Які сонячні хмари - й синь бездонних небес! (3, с. 68); Які сонячні хмари! Яка казка навкруг! (3, с. 68);

б) звукові кореляти актуалізують протистояння добра / зла на рівні біблійної настанови й біблійних пророчих дискурсів: $A$ над землею сатанинський рик несамовито вимагає: - Крові! (3, с. 21); відтворюють історично позначену синестезійну емоцію (голосіння - обірвана пісня): I вдів голосіння, й обірвана пісня... Хитається спогадом спалений світ (3, с. 42); асоціація звуку й усталеного поняття має алюзійний контекст: Плакучі верби. Тихий сквер мовчить. Князь Святослав навіки тут спочив (3, с. 31);

в) густативні кореляти, побудовані на оксиморонній природі художнього образу: Мов ковток крижаної гіркої води, ия оманлива вольная дійсність (3, с. 22-23).

Синестезія становить системну ознаку естетичної чуттєвості, зумовлює новий підхід до дослідження проблеми чуттєвості; можемо говорити про актуальність теоретичного обгрунтування й аналізу практичного втілення можливостей об'єднання різних 
типів сприйняття, взаємозв'язку відчуттів в акті сприйняття як реальної дійсності, так і художнього дискурсу, дослідження структури полімодального сприйняття на рівні системи образів, а також стилетвірного чинника ідіостилю, коли в єдиному когнітивному акті відбувається задіяння різних за типом асоціацій, i $€$ одним із напрямків нового погляду на художній потенціал мовних одиниць у складі синестезійних образів.

Мовний матеріал (на прикладі літератури рідного краю) засвідчує функціонування відчуттєвих мовних корелятів, які репрезентують складні психологічні стягнення, актуалізують сенсорно-емоційний складник, утворюючи синестезійні образи. Синестеійні образи становлять стилістичний ресурс, засвідчують автохтонність літературної традиції.

\section{Література}

1. Дмитренко Н. Звук і колір: феномен синестезії у творчому мисленні Я. Івашкевича (на матеріалах українськомовних видань) / Н. Дмитренко. [Електронний ресурс]. - Режим доступу : http://ijimv.knukim.edu.ua/zbirnyk/3_1/8Dmytrenko.pdf

2. Дудик П. С. Стилістика української мови : [навчальний посібник]. - К. : ВЦ «Академія», 2005. - 368 с.

3. Омельченко О. О. Вселюбов : Поезії, поеми, балади, драми, уривок 3 роману / О. О. Омельченко. - Дніпропетровськ : ВАТ «Дніпрокнига» 2006. -319 с.

4. Сарнавська О. В. Інваріантність інтерпретації синестезії та іï роль в естетичній чуттєвості / О.В. Сарнавська. - [Електронний ресурс]. - Режим доступу : http://www.zgia.zp.ua/gazeta/VISNIK_42_15.pdf

Стаття надійшла до редакиії 18.02.2018 p. 